А. О. Волосовець, І. С. Зозуля, В. І. Боброва, О. В. Іващенко, І. В. Вербицький, О. Г. Крамарева, А. В. Бойко

Національний університет охорони здоров'я України імені П. Л. Шупика, Київ

\title{
НОВІ ФОРМИ ПІСЛЯДИПЛОМНОГО ДИСТАНЦЙНОГО НАВЧАННЯ ЛІКАРІВ НА КАФЕДРІ МЕДИЦИНИ НЕВІДКЛАДНИХ СТАНІВ
}

\author{
A. O. Volosovets, I. S. Zozulya, V. I. Bobrova, O. V. Ivashchenko, \\ I. V. Verbytsky, O. G. Kramareva, A. V. Boyko \\ Shupyk National Healthcare University of Ukraine, Kyiv

\section{NEW TYPES OF POSTGRADUATE DISTANCE EDUCATION OF DOCTORS IN DEPARTMENT OF EMERGENCY MEDICINE}

\begin{abstract}
Анотація. Особливості розвитку сучасних концепцій дистанційної освіти для післядипломної підготовки і навчання лікарів медицини невідкладних станів та суміжних спеціальностей в умовах поширення інфекції COVID-19 потребують впровадження у навчальний процес нових, більш ефективних навчальних методик. Однією з таких методик є проведення воркшопу (workshop) в дистанційному форматі.

Мета статті - оцінка ефективності навчального процесу для лікарів медицини невідкладних станів та суміжних спеціальностей за умови використання воркшопу як ефективної дистанційної навчальної технології.

Для збільшення ефективності дистанційного формату післядипломної підготовки лікарів на кафедрі медицини невідкладних станів Національного університету охорони здоров'я імені П. Л. Шупика в практику викладання була введена така навчальна технологія, як воркшоп, що має низку переваг у вигляді розвитку у слухачів активності, самостійності та стимуляції до взаємного обміну знань. Наведений приклад воршопу щодо діагностики та лікування гострого ішемічного інсульту.

Воркшоп є ефективною навчальною технологією оволодіння новими знаннями, яка має знайти широке використання в практиці післядипломної освіти лікарів медицини невідкладних станів та суміжних спеціальностей.
\end{abstract}

Ключові слова: воркшоп; медицина невідкладних станів; інсульт; дистанційна освіта.

Abstract. Modern challenges in distance education of emergency medics in situation of further spreading of COVID-19 require an implementation of modern effective educational technologies into the educational process. One of those technologies is workshop.

The aim of the work - introduction of workshop as an effective distant educational technology for postgraduate training of emergency medics.

In order to increase the effectiveness of postgraduate education of emergency medics at the Department of Emergency Medicine we have decided to implement such educational technology as workshop. It has a number of advantages in instilling in students such skills as activity, independence and stimulation of mutual knowledge exchange. In this article we have presented an example of a workshop about the diagnosis and treatment of stroke.

Workshop is an effective educational technology for acquiring new knowledge, which should be widely used in the postgraduate education of doctors.

Key words: workshop; emergency medicine; stroke; distant education.

Вступ. Особливості розвитку сучасних концепцій дистанційної освіти для післядипломної підготовки і навчання лікарів з медицини невідкладних станів та суміжних спеціальностей в умовах поширення інфекції COVID-19 потребують впровадження у навчальний процес нових, більш ефективних навчальних методик. Однією з таких методик є проведення воркшопу (workshop) в дистанційному форматі [1, 2].
«Воркшоп» (workshop (англ.) - майстерня) - це навчальний захід (що стає на одному рівні із семінарами, тренінгами, курсами, стажуваннями), на якому учасники отримують знання самостійно, працюючи не тільки з викладачем, але і один з одним [3].

Основні критерії, характерні саме для цієї форми навчання, полягають в інтенсивній груповій взаємодії суб’єктів навчання під керівництвом ви-

(c) А. О. Волосовець, І. С. Зозуля, В. І. Боброва та ін. 
кладача, високій мотивації всіх учасників, високому рівні самостійності та активності слухачів у процесі здобуття знань. Викладач, який є модератором воркшопу, повинен мінімізувати свій вплив у процесі заняття та лише допомагати студентам визначити мету, завдання воркшопу і рекомендувати учасникам необхідні дидактичні та методичні інструменти для досягнення цієї мети $[4,5]$.

Мета статті - оцінка ефективності навчального процесу для лікарів медицини невідкладних станів та суміжних спеціальностей за умови використання воркшопу як ефективної дистанційної навчальної технології.

Теоретична частина. Для збільшення ефективності дистанційного формату післядипломної підготовки лікарів на кафедрі медицини невідкладних станів Національного університету охорони здоров'я імені П. Л. Шупика в практику викладання була введена така навчальна технологія, як воркшоп, що має низку переваг у вигляді розвитку у слухачів активності, самостійності та стимуляції до взаємного обміну знань.

У процесі проведення воркшопу викладач намагається відійти від жорсткої педагогічної моделі директивної трансляції знань від викладача до слухачів. При цьому активно стимулюється залучення слухачів до активного процесу оволодіння знаннями, власного пошуку рішень і засвоєння нових знань та вмінь.

Воркшоп є унікальною методикою навчання, де процес навчання від викладача поєднується з процесом навчання від іншого слухача й надає унікальну можливість самому стати викладачем і ментором в деяких аспектах тематики, що вивчається. Таким чином, воркшоп $є$ також своєрідним індикатором рівня знань та вмінь слухачів за темою, що вивчається. Для викладача залишається важливим завданням надавати слухачам установку на командні дії у випадку невідкладної медичної ситуації і тактовно спрямовувати ці дії у правильному напрямі щодо особливостей конкретної клінічної ситуації, стимулюючи при цьому розвиток клінічного мислення та командної роботи у слухачів.

Оптимальна тривалість воркшопу на медичну тематику - до 2-3 год. Основні методи і прийоми включають аналіз і розбір клінічного кейсу, розробку тематичної лекції у вигляді вступної презентації для моделювання ситуації, подання інформації щодо засад спілкування та елементів конфліктології при роботі у групі, практику «мозкового штур- му» в колективі групи, демонстрацію виконання індивідуальних і групових медичних маніпуляцій. Лекційна складова викладача у воркшопі має бути мінімізована до обсягу, що дозволяє освіжити знання слухачів за темою заняття.

Елемент дебрифінгу дозволяє наприкінці воркшопу у процесі дискусії одній групі студентів обговорювати дії другої групи у невідкладній клінічній ситуації. Після завершення воркшопу у слухачів повинні бути напрацьовані та закріплені певні набуті знання, уміння і компетенції для надання медичної допомоги у певній клінічній ситуації. Цей динамічний процес оволодіння знаннями не допускає ознак будь-якої пасивності від учасників, тому при оцінці результативності заходу необхідно визначити та враховувати конкретний внесок кожного з учасників.

Нижче наводимо приклад воркшопу для лікарів медицини невідкладних станів та суміжних спеціальностей, присвячений темі діагностики та лікування гострого мозкового інсульту.

План навчального воркшопу на тему «Гострий мозковий інсульт»

Ведучий: викладач кафедри медицини невідкладних станів.

Актуальність. Зростання частоти виявлення цереброваскулярної патології обумовлює актуальність адекватної підготовки лікарів медицини невідкладних станів та суміжних спеціальностей в аспекті діагностики та лікування гострого мозкового інсульту за допомогою нових методів дистанційного навчання.

Мета та кінцевий результат навчального воркшопу - опановуючи технологію діагностики і лікування гострого мозкового інсульту для післядипломної підготовки лікарів медицини невідкладних станів та суміжних спеціальностей, висвітлити питання розвитку та особливостей перебігу клінічних варіантів порушення мозкового кровообігу, розкрити особливості диференційної діагностики та надання медичної допомоги на догоспітальному і ранньому госпітальному етапах, навчити лікарів застосовувати у практичній роботі алгоритми сучасної діагностики та невідкладної допомоги пацієнтам із гострим мозковим інсультом.

Оснащення: комп’ютер, підключений до мережі «Інтернет». Необхідне програмне забезпечення Zoom, Google Meet, Skype тощо.

Вибір форми обумовлений необхідністю забезпечення післядипломного навчального про- 
цесу зі спеціальності «Медицина невідкладних станів».

Форма: поєднання теоретичної вступної короткої лекції з наступним аналізом та клінічним розбором різних клінічних випадків гострого мозкового інсульту з наданням максимального рівня самостійності слухачів. Учасники воркшопу використовують наявний досвід і набуті на попередніх курсах знання та вміння щодо оцінки стану пацієнта. Вони діляться цією інформацією з іншими учасниками заходу. Ведучий визначає клінічні кейси (ішемічний мозковий інсульт, геморагічний мозковий інсульт), контролює процес, спрямовує діяльність на активізацію груп.

Для кого спрямований: лікарів-інтернів, лікарів із медицини невідкладних станів та лікарів суміжних спеціальностей.

Перед воркшопом. Інформація про навчальний контент воркшопу (найменування, зміст, дата, час проведення) розміщується в Інтернет за 1,5 тижня до початку навчального воркшопу та надсилається слухачам на електронні адреси. Варто інформувати майбутнього слухача одразу про успішну реєстрацію для участі в заході та надіслати електронний лист із нагадуванням. Також необхідна підготовка листа із можливими ситуаційними задачами щодо стимуляції індивідуальної активності та мотивації слухачів з урахуванням їх роботи у різних групах.

Загальна кількість учасників: 12.

Кількість груп: 2.

Розмір однієї групи: 6 учасників.

Підготовка інформаційного листа з порадами для учасників воркшопу:

- заходити в чат за 5-10 хв до початку;

- вказувати своє ім'я (не деперсоналізований нікнейм);

- вітати учасників воркшопу;

- не провокувати та не уникати конфліктів між учасниками воркшопу;

- чат використовувати тільки для тематичного обговорення.

Підготовку до проведення воркшопу варто починати мінімум за 30 хв до запланованого початку заходу з урахуванням того, що доступ до платформи для слухачів відкривається за 10 хв. Викладач пояснює учасникам правила комунікації. Найпоширеніші способи - підняти руку, поставити питання по мікрофону або написати його в чаті.

Зміст/план навчального воркшопу:
1. Вступ.

2. Вступна коротка лекція, що визначає актуальність проблеми гострого мозкового інсульту як невідкладного стану, що загрожує життю пацієнта (лекція з презентацією Power Point).

3. Ознайомлення слухачів із сучасними підходами до діагностики та лікування гострого мозкового інсульту.

4. Колективне обговорення проблематики теорії прийняття рішень лікарем у критичній ситуації щодо набряку головного мозку у пацієнта з мозковим інсультом.

5. Практикум у вигляді аналізу і розбору кожною групою конкретних клінічних кейсів.

6. Групова дискусія.

7. Активне оцінювання учасників кожної групи за участю інших груп студентів за методом дебрифінгу.

8. Оцінювання активності студентів та проведеної роботи викладачем.

Конкретні техніки та вправи для різних етапів воркшопу:

- на етапі мотивації: активізація слухачів, визначення груп, підкреслення актуальності визначеної проблематики мозкового інсульту;

- на етапі засвоєння теоретичних знань - практично-орієнтоване подання інформації щодо засад спілкування та елементів конфліктології (патофізіологія мозкового інсульту, особливості контакту 3 пацієнтом);

- на етапі колективного обговорення - аналіз і розбір ситуацій в розрізі сучасних психологічних практик та етичних положень (допустимість госпіталізації, способи заспокоєння та стабілізації стану пацієнта);

- на етапі навчання (оволодіння практичними навичками спілкування) кожна група проводить «мозковий штурм» для вирішення свого кейсу та розробляє спільну презентацію алгоритму дій для даної ситуації (вирішення конкретного клінічного випадку пацієнта з мозковим інсультом);

- на етапі підготовки до дискусї - підтримка активності учасників та їх самостійності й аргументованості у прийнятті рішень;

- на етапі групової дискусї - інтенсивна групова взаємодія, уникнення проблемних ситуацій у спілкуванні (обговорення описаних алгоритмів допомоги, критика та виправлення помилок у лікуванні та діагностиці); 
- на етапі активного оцінювання - дебрифінг 3 боку інших учасників воркшопу.

Графік воркшопу: он-лайн вступна лекція - 30 хв, практикум із вирішенням ситуаційних завдань у декількох групах - 60 хв, підбиття підсумків - 45 хв та оцінювання -45 хв.

Структура проведення. Головні відмінності, що притаманні воркшопу на відміну від заходів іншого типу, - висока інтенсивність інтрагрупової взаємодії, активність і самостійність учасників груп, актуальний досвід, особисте переживання кейсу.

Вид освітнього процесу: участь у навчальному воркшопі.

Форма освіти або підвищення кваліфікації: очна та дистанційна очна.

Вартість надання освітньої послуги: участь безкоштовна.

Напрямок - розвиток професійних та особистісних компетентностей лікаря щодо діагностики та догоспітального і раннього госпітального лікування гострого мозкового інсульту.

\section{Список літератури}

1. Про запобігання поширенню на території України коронавірусу COVID-19 : Постанова Кабінету Міністрів України від 11 берез. 2020 р. № 211.

2. Про затвердження Положення про дистанційне навчання : наказ Міністерства освіти і науки України від 25 квіт. 2013 р. № 466.

3. Distance Education. - https://www.tandfonline.com/ toc/cdie20/current.

\section{References}

1. Postanova Kabinetu Ministriv Ukrainy Pro zapobihannia poshyrenniu na terytorii Ukrainy koronavirusu COVID-19 vid 11 bereznia 2020 r. № 211 [Resolution of the Cabinet of Ministers of Ukraine On prevention of the spread of coronavirus COVID-19 on the territory of Ukraine of March 11, 2020 No. 211] [in Ukrainian].

2. Nakaz Ministerstva osvity i nauky Ukrainy Pro zatverdzhennia Polozhennia pro dystantsiine navchannia vid 25.04.2013 r. № 466 [Order of the Ministry of

\section{Набуті компетентності:}

- сучасні технології експрес-діагностики і лікування гострого мозкового інсульту на догоспітальному етапі, комунікації з родичами хворої людини;

- навички щодо прийняття рішучих й обгрунтованих рішень у невідкладній ситуації (набряк головного мозку).

Тривалість воркшопу: 4 год - кредит ЄКТС: 0,13. Після воркшопу. Коли воркшоп закінчений, викладач направляє учасникам електронні листи з підсумками та результатами заходу і посилання на джерела, що використовувалися під час презентації.

Висновки. Воркшоп $є$ ефективною навчальною технологією для оволодіння новими знаннями, яка однаково ефективно може використовуватись і в очному, і в дистанційному форматах. Цей метод необхідно широко застосовувати у підготовці лікарів медицини невідкладних станів та суміжних спеціальностей, особливо в умовах пандемії.

4. http://osvita.ua/vnz/add-education/glossary/7701/.

5. Naidu S. Building resilience in education systems postCOVID-19 / Som Naidu // Distance Education. - 2021. - Vol. 42, Issue 1. - P. 1-4. DOI 10.1080/01587919.2021.1885092.

Education and Science of Ukraine On approval of the Regulations on distance learning dated 25.04. 2013 No. 466] [in Ukrainian].

3. Distance Education. Retrieved from: https://www. tandfonline.com/toc/cdie20/current.

4. http://osvita.ua/vnz/add-education/glossary/7701/.

5. Naidu, S. (2021). Building resilience in education systems postCOVID-19. Distance Education, 42(1), 1-4. DOI 10.1080/01587919.2021.1885092. 